\title{
Damage Distribution in Class Actions: The Cy Pres Remedy
}

Under revised rule 23 of the Federal Rules of Civil Procedure, the judgment in a class action binds all class members who have not acted to exclude themselves from the suit. ${ }^{1}$ This provision represents the drafters' judgment that although many class members would not respond to a request for affirmative action, ${ }^{2}$ silence does not signify opposition to the maintenance of the suit. ${ }^{3}$ This assumption has created a problem in large class actions for damages where class members remain silent even after a judgment or settlement in their favor has been reached and do not attempt to collect their shares of the recovery. ${ }^{4}$ If the inaction of class members permits retention of the uncollected damages by the defendant, the result may be the effective exclusion of a substantial number of small claimants from the benefits of any class action, the dilution of the deterrent effect of a recovery on behalf of the class, and the unjust enrichment of the defendant.

Perhaps as significant as this partial destruction of the effectiveness of the class action is the problem of manageability, which may eliminate many large class actions in their incipiency. Most class actions are subject to the requirement of rule $23(\mathrm{~b})(3)$ that before the suit may proceed, the class action device must be found superior to other available

\footnotetext{
1 FED. R. Crv. P. 23(c)(3) provides:
}

The judgment in an action maintained as a class action under subdivision (b)(1) or (b)(2), whether or not favorable to the class, shall include and describe those whom the court finds to be members of the class. The judgment in an action maintained as a class action under subdivision (b)(3), whether or not favorable to the class, shall include and specify or describe those to whom the notice provided in subdivision (c)(2) was directed, and who have not requested exclusion, and whom the court finds to be members of the class.

2 It had been suggested that the judgment in a class action under rule 23(b)(3) should embrace only those individuals who, in response to notice of the action, communicated with the court to indicate their desire to be included. Frankel, Amended Rule 23 from a Judge's Point of View, 32 ANTrTR. L.J. 295, 299-300 (1966).

3 Kaplan, Continuing Work of the Civil Committee: 1966 Amendments to the Federal Rules of Civil Procedure, 81 HARv. L. REv. 356, 397-98 (1967).

4 In the tetracycline antitrust cases after notice of settlement and a request for the filing of individual claims had been published in every newspaper of general circulation in the country, thirty-eight thousand claims were filed by members of a consumer class numbering in the tens of millions. This lack of response resulted in approximately $\$ 20$ million in unclaimed funds. West Virginia v. Chas. Pfizer \& Co., 440 F.2d 1079, 1089-84 (2d Cir. 1971), aff'g 314 F. Supp. 710 (S.D.N.Y. 1970). 
methods for the fair and efficient adjudication of the controversy. 5 The prospect that a substantial portion of the class will not share in the recovery makes the superiority of the class action device doubtful. As the Second Circuit has stated, courts are "reluctant to permit actions to proceed where they are not likely to benefit anyone but the lawyers who bring them." 6 The inability of the court and counsel to effectuate recovery by silent class members constituting a substantial portion of the class may thus result in dismissal of the suit. ${ }^{7}$

In response to these difficulties, courts and counsel are currently attempting to solve the problems of uncollected damages in the class action context. Two very different approaches are available: (1) elimination of the causes of the large uncollected damage pool, or (2) an attempt to make an appropriate disposition of these uncollected funds. This comment will examine these possible alternative resolutions of the uncollected damages problem with respect to their ability to promote an economical and equitable solution.

\section{Elimination of the Factors Creating Uncollected Damages}

\section{A. Redefinition of the Class}

Several procedures for redefining the plaintiff class have been adopted by courts in order to avoid the problem of uncollected damages. The first procedure is to redefine the class to include only those persons who, prior to commencement of the trial on the merits, either indicate affirmatively that they intend to claim their shares of the recovery or submit the amount of their claims to the court. ${ }^{8}$ A second is to include only those persons whom the court determines to have the most significant and substantial claims against the defendants. ${ }^{\circ} \mathrm{A}$ third is to include only those persons who come forward to claim their shares of the recovery within a specific period after a judgment on the merits.

5 FED. R. Crv. P. 23(b)(3).

6 Eisen v. Carlisle \& Jacquelin, 391 F.2d 555, 567 (2d Cir. 1968).

7 See Philadelphia v. American Oil Co., 53 F.R.D. 45 (D.N.J. 1971). A suit was held not to be maintainable as a class action largely because the class members would not come forward to prove and collect their damages and no feasible means had been found for distributing damages to the class.

8 See Minnesota v. United States Steel Corp., 44 F.R.D. 559 (D. Minn. 1968); Philadelphia Elec. Co. v. Anaconda Am. Brass Co., 43 F.R.D. 452 (E.D. Pa. 1968); Iowa v. Union Asphalt \& Roadoils, 281 F. Supp. 391 (S.D. Iowa 1968); Harris v. Jones, 41 F.R.D. 70 (D. Utah 1966); Newberg, Orders in the Conduct of Class Actions: A Consideration of Subdivision (d), 10 B.C. IND. \& CoM. L. REv. 577 (1969).

9 See Illinois v. Harper \& Row Publishers, 301 F. Supp. 484 (N.D. Ill. 1969); Philadelphia Elec. Co. v. Anaconda Am. Brass Co., 43 F.R.D. 452 (E.D. Pa. 1968). This solution largely eliminates the problem of uncollected damages since it is assumed that those with substantial claims have an incentive to collect them. 
Despite their success in eliminating uncollected damages, these procedures are unsatisfactory in that they lead to unjust enrichment of the defendant and decrease the deterrent effect of the judgment. They also clearly seem to undercut the intent of the 1966 revision of rule 23 since they run directly contrary to the drafters' decision to include in class actions those who have made no affirmative effort to join the suits. ${ }^{10}$ Moreover, by reducing the size of the class included in the judgment and thus the amount of the eventual recovery, the first two approaches would also reduce the fee of the plaintiffs' attorney and his incentive to prosecute the action. To the extent that the maintenance of a class action under rule 23 is dependent on the initiative of the plaintiffs' attorney, ${ }^{11}$ these approaches might significantly decrease the number of suits brought on behalf of small or unidentifiable claimants.

Unlike the tactic of eliminating class members prior to allowing the action to proceed, the third procedure, by including those who come forward to collect their damages after a judgment on the merits, would at least allow plaintiffs to attempt to redress their grievances in a class action. The probability that class members would claim damages due them may be greater after a judgment in their favor than before any decision on the merits. Moreover, the class action would remain economically viable since the amount of potential damages would not be diminished.12

But even if the judgment were kept open indefinitely, rather than for a limited period, to allow class members to collect their damages, it is not likely that the previously silent members would fare significantly better. Unless additional notices informing class members of the settlement or judgment in their favor were given, the great majority of class members who had not come forward to collect their damages during the initial period would probably never do so. The mere passage of time would not stimulate action by those previously silent.

\section{B. Required Documentation of Transactions}

Where the transactions are sufficiently documented to permit the identity of the class members and the quantity of their purchases

10 Kaplan, supra note 3, at 397-98.

11 See Dolgow v. Anderson, 43 F.R.D. 472, 485 (E.D.N.Y, 1968); Kalven \& Rosenfield, The Contemporary Function of the Class Suit, 8 U. CHr. L. REv. 684, 716-17 (1941).

12 This is attributable to the dependence of the class action on the initiative of the class attorney and the fee incentive of a large potential recovery, assuming that the attorney's fee will continue to be based on the aggregate damages rather than only the amount of damages the class members actually collect. 
during the relevant period to be ascertained, it might be possible to distribute the class members' shares of the recovery to them directly without affirmative action on their part. This situation typically occurs in recoveries by utility customers or credit card holders where the defendant has a record of transactions for each consumer and may distribute damages merely by crediting his account or by sending him a check. ${ }^{13}$

The problem of uncollected damages could be partially solved in the future by requiring that certain kinds of transactions ${ }^{14}$ be documented to the extent necessary to calculate and distribute class action damages. ${ }^{15}$ But even if such records were made and preserved for a substantial period of time, class members no longer doing business with the companies nor residing at their old addresses would still generate uncollected damages. ${ }^{16}$ It must also be recognized that this procedure would not alleviate the problem of uncollected damages in cases currently pending before the courts. Moreover, the cost of the documentation required by this approach would be passed on to the consumer, and the resulting price increase might be less desirable than the uncompensated loss it was designed to eliminate.

In summary, the alternatives for eliminating the causes of uncollected damages do not appear to provide an acceptable solution to the uncollected damages problems currently confronting the courts. The class redefinition procedures both undercut the thrust of rule 23 by excluding many small claimants from the benfits of a class action and permit the unjust enrichment of the defendant. Greater documentation of consumer transactions may be an effective prospective solution, but it is not an available remedy where the transactions on which the claims are based have already occurred. If there is an efficacious solution to the problem, therefore, it must be found in an appropriate distribution of the uncollected damages.

13 See Illinois Bell Tel. Co. v. Slattery, 102 F.2d 58 (7th Cir. 1939). After a rate reduction had been upheld, the utility was able to distribute all but $\$ 1,688,795.68$ of a total $\$ 18,798,980.14$ in overcharges through cash distributions or credits to accounts. The expenses of distribution approached $\$ 3$ million, but it is expected that with the use of computers, this cost could be substantially reduced.

14 Ideally, all consumer contracts for the sale of goods or services would be so documented. It is assumed that adequate records are already being kept for most commercial transactions.

16 This necessary documentation may develop as the economy moves toward greater use of the credit card, but the area of cash sales remains a significant obstacle.

16 This situation could be alleviated where forwarding addresses were available, although some difficulty and not insignificant expense in tracing would undoubtedly be encountered. 


\section{Distribution Alternatives: The Cy Pres Remedy}

If the court allows the action to proceed on behalf of all class members who have not acted to exclude themselves from the suit, there are several alternatives available for the distribution of the uncollected damages that will result. It may still be possible, for example, to distribute the damages to a "next-best" class composed partially of plaintiff class members. This procedure of finding a next-best recipient for the funds is analogous to the doctrine of cy pres.

The cy pres doctrine is a rule of construction utilized by courts to effectuate testamentary charitable gifts that would otherwise fail. Where intervening circumstances have rendered a testamentary charitable gift impossible, as where the charitable object no longer exists, the court will make a factual determination of the testator's intent. If the testator had the intent to accomplish only the specific purpose that has since become impossible (e.g., to benefit only a specific Catholic church), the gift must fail. If the testator had a general charitable intent (e.g., to benefit any Catholic church), the court will look for an alternate donee that will best serve the testator's original purpose. ${ }^{17}$ The function of the court is to comply as closely as possible with the intent of the testator. ${ }^{18}$ In some cases, the court will consider the degree to which a possible plan would be of public service, ${ }^{10}$ and this consideration increases in importance "with the transition from emphasis on the individual to society as a whole."20

When distribution problems arise in large class actions, courts may seek to apply their own version of cy pres by effectuating as closely as possible the intent of the legislature in providing the legal remedies on which the main cause of action was based. Legislative intent may frequently not offer clear guidelines since the usual intent in providing statutory remedies is to compensate only the injured parties. ${ }^{21}$ Where

17 E. Fisch, The Cx Pres Docrrine in the United States 128 (1950).

18 In ascertaining the testator's intent, the court may look to the language of the document establishing the gift, the charitable gifts made by the testator in the past, the general purpose avowed by the original donee or, in those cases in which the testator has manifested an intent to benefit the residents of a particular locality, the geographic region of the original donee. See E. Fiscr, supra note 17, at 216-18.

19 See Estate of Butin, 81 Cal. App. 2d 76, 83, 183 P.2d 304, 308 (1948). Funds had been left for the construction of a memorial carillon "dedicated to the memory of all those who strove to make Madera and Madera County all that it is." When the project became impractical, the court stated that a substitute memorial might consist of a health center.

20 E. Fisch, supra note 17, at 219.

21 It is reasonable to assume that the general intent to compensate only the injured parties should be the guiding principle where the class action is based on the common law rather than on a statute. There may be a problem, however, where the legislature's choice of a next-best recipient of the uncollected damages fails to approximate the plaintiff class. 
it is impossible, however, to reach only those injured, and where proposed remedies will also benefit some nonclass members, courts will attempt to ascertain which alternate recipients the legislature would prefer. As it becomes more difficult, or even impossible, to ascertain which alternate recipients the legislature would prefer, it may be appropriate to devote the funds to a broader public service in order to maximize the benefit to society.

Three general cy pres approaches are available for the disposition of uncollected damages: (1) distribution to those class members who come forward to collect their damages, (2) distribution through the state in its capacity as parens patriae or by escheat, and (3) distribution through the market.

\section{A. Distribution to Members Filing Claims}

An initial cy pres remedy would be to divide the uncollected damages among those class members who do collect their shares. Those individuals could be considered a next-best class because the injuries they have incurred are similar to those of the silent class members. Moreover, distribution among those filing claims would neither diminish the deterrent effect of the judgment nor unjustly enrich the defendant. Nevertheless, this method expressly contemplates that silent class members will not receive any compensation, even indirectly. The claims of the silent class members would be expropriated and a windfall might result for those who appeared and collected their share of the damages. Consequently, this procedure might encourage the bringing of class actions likely to result in large uncollected damage pools. It also raises serious questions as to the adequacy of representation where the interests of the named plaintiffs lie in keeping the other class members uninformed. ${ }^{22}$ In sum, the deficiencies of this method of distribution make it a generally unacceptable alternative.

\section{B. Distribution Through the State}

Another method would be to distribute the uncollected damages through the state. The next-best class would consist of either (1) the general population of the state, if the funds were given unconditionally, or (2) those groups who benefited from particular governmental expenditures, if the funds were given subject to the condition that they

In this situation, the legislative preference should be honored, but it may be desirable for the court to solicit the class members more actively to collect their damages if indirect distribution to them is not to be attempted.

22 Rule 23 provides significant safeguards of the interests of the unnamed class members, but it seems clear that the best safeguard is a close identity of interests between the named plaintiffs and the other class members. 
be allocated to certain programs. The authority for the state to serve as intermediate recipient of the funds is based on the state's position as parens patriae ${ }^{23}$ and on the general theory of escheat. ${ }^{24}$

The Supreme Court recently confronted a similar problem in Hawaii v. Standard Oil Co., ${ }^{25}$ in which it held that a state may not sue as parens patriae for treble damages under the Glayton Act. The State of Hawaii had sought to recover either damages for antitrust violations based on the alleged injury to the economy of the state over and above the injury to individual consumers or, alternatively, aggregate damages based on the alleged injury to the individual consumers within the state. Although denying recovery on either theory on the basis of its interpretation of the Clayton Act, the Court did note that a class action under rule 23 would be the appropriate means for redressing the injuries to consumers within the state. ${ }^{28}$ The Court was concerned about the use of the parens patriae theory as a means to circumvent the safeguards of rule 23, the possibility of double recovery where both the state and the consumers are permitted to bring suits for the same damages, and the state's expropriation of the claims of consumers. It seems clear that these reasons for the restrictive interpretation of parens patriae suits for damages would not bar the state's claim to the uncollected damages recovered in a class action. ${ }^{27}$ The safeguards of rule 23 would be satisfied, double recovery would not be a problem since class members who had not excluded themselves would be bound by the judgment, and the consumer claims would not be expropriated if a reasonable time were provided during which class members could collect their damages.

23 The term parens patriae has traditionally described the power of the sovereign to act as guardian for persons under legal disability to act for themselves. Parens patriae suits include cases in which the state acts as guardian or trustee for juveniles, In re Turner, 94 Kan. 115, 120, 145 P. 871, 872 (1915); the insane, Mormon Church v. United States, 136 U.S. 1, 58 (1890); and the unknown, id. In the United States, the doctrine has been expanded to include cases in which a state seeks redress for injuries to its quasi-sovereign interests (e.g., its general economy or environment)-interests that the individual citizens within the state would not have standing to assert. See Georgia v. Tennessee Copper Co., 206 U.S. 230 (1907); Kansas v. Colorado, 206 U.S. 46 (1907).

24 The question of whom the state represents in this procedure would seem to depend on the kinds of restrictions imposed on the state's use of the funds. Under traditional parens patriae doctrine, the state represents those who cannot individually collect their shares of the class action recovery. As a practical matter, however, the state acts in the interests of the silent class members only to the extent that the money it collects is used for their benefit. Where the funds collected by the state are not subject to restrictions, the state is actually representing the general public as the next-best recipient.

2592 S. Ct. 885 (1972).

26 Id. at 893.

27 See Comment, State Protection of Its Economy and Environment: Parens Patriae Suits for Damages, 6 Colum. J.L. \& Soc. Pros. 411, 424 (1970). 
The opportunity for the state as parens patriae to assert its claim to the uncollected damages could arise in two contexts: (1) when the state, having sustained an injury in its proprietary capacity, sues as class representative in an action under rule 23 on behalf of all injured purchasers, or (2) when the state seeks to intervene in a class action prosecuted by a private party. ${ }^{28}$ In both situations, upon recovering damages sustained in its proprietary capacity as a class member, the state could propose that it serve as alternate recipient of all uncollected damages. It is not necessary, of course, for the state to intervene in order to serve as alternate recipient of the funds. If the state had not been injured in its proprietary capacity, its participation as recipient of the funds could still be asserted by the class representative or by the court sua sponte. ${ }^{29}$

If the state were allowed to claim the damages not collected by silent class members, there would remain the question whether the state should have unconditional or restricted use of the funds. There are two major objections to allowing unconditional retention by the state. First, as residents of the state,$^{30}$ the silent class members might be said to benefit indirectly to the extent that the funds were used to expand government programs or to reduce taxes. Distribution of the funds to the general population would not, however, be a very close approximation to the ideal solution of returning the damages to the actual class members. Second, when the funds went to the unrestricted public coffers, the recovery would appear to be more like a fine or penalty than like compensatory damages. ${ }^{31}$

28 Where the state had been injured in its proprietary capacity, intervention would be as of right. FED. R. Crv. P. 24.

29 The state is not the only governmental unit that may serve as a recipient for the uncollected damages. The federal government or a local governmental unit may be the proper participant where it is best able to effectuate a distribution for the benefit of the plaintiff class. The decision concerning which of these governmental units to select as recipient should be a pragmatic one based on their relative abilities to achieve an efficient and equitable distribution of the funds to a next-best class. In many situations, it is likely that the best method of allocation would be to divide the funds among the governmental units according to the proportion of residents of each unit in the class of injured persons. One method of calculating this figure would be to determine the residency of class members who have filed claims with the court. See West Virginia v. Chas. Pfizer \& Co., 440 F.2d 1079, 1084 (2d Cir. 1971). In some situations, however, there might be a conflict between the allocation of the funds to the entity most able to effectuate an efficient and equitable distribution and the attempt of each governmental unit to claim the damages uncollected by its residents. In such cases, allocation of the funds to the body most capable of effectuating an efficient and equitable distribution would be preferable.

30 In some cases, distribution would not be according to residency. See note 29 supra.

31 This result would be especially anomalous because cy pres is an equitable remedy, and equity has traditionally not recognized punitive damages. Annot., 48 A.L.R.2d 947 
Both objections are unconvincing. While the general population of the state would be only an approximation of the silent class, distribution to this next-best class would clearly be preferable to the unjust enrichment of the defendant. Moreover, damages are not transformed into penalties merely because the state is the recipient. From the defendant's perspective, since the damages would have been calculated on the basis of the actual injury to the class, they would be the same regardless of the identity of the immediate recipient. Furthermore, one may question whether the defendant is the proper party to challenge the extent to which the plaintiff class may be benefited by a recovery.

A court might more narrowly define the next-best class, of course, by imposing restrictions on the state's disposition of the uncollected damages. Through this "conditional escheat" procedure, it would be possible both to retain the advantages of providing for complete recovery through use of the state's claim to the uncollected damages and to achieve the goal of more closely approximating compensation for the injured class members. This procedure has been suggested as a means of distributing the uncollected portion of the settlement fund in the tetracycline antitrust actions, ${ }^{32}$ in which each of several states sued in its proprietary capacity as representative of a governmental class, and the state attorney general in his individual capacity as representative of a consumer class, for damages resulting from an alleged price-fixing conspiracy. The rule 23 notice of settlement, which had been given to members of the consumer class by publication, stated that individual claims would be accepted for a period of approximately ninety days and that the failure to file an individual claim would "constitute an authorization to the Attorney General ... to utilize whatever money he may recover as [class] representative for the benefit of the citizens of [the] State in such manner as the court may direct."33 During the ninety-day period, approximately thirty-eight thousand consumer claims were filed, aggregating to about $\$ 16$ million. ${ }^{34}$ It is expected that approximately $\$ 10$ million of these will be allowed by the court, ${ }^{35}$ leaving about $\$ 27$ million of uncollected consumer claims. The attorney for seven of the states ${ }^{36}$

(1956). But of. Starrs, The Consumer Class Action-Part I: Considerations of Equity, 49 B.U.L. REv. 211, 218-19 (1969).

32 West Virginia v. Chas. Pfizer \& Co., 440 F.2d 1079 (2d Cir. 1971).

33314 F. Supp. 710, 725 (S.D.N.Y. 1970).

34440 F.2d 1079, 1083 (2d Cir. 1971).

35 Individual claims were investigated, and reduction or disallowance of some claims was recommended to the court. Interview with Lee A. Freeman, Sr., attorney for plaintiffs, in Chicago, Mll., Jan. 24, 1972 [hereinafter cited as Freeman Interview].

36 The governmental units to which this applies are Colorado, Illinois, Indiana, Michigan, New Hampshire, Pennsylvania, West Virginia, the City of Chicago, the Metropolitan Government of Nashville, and Davidson County, Tennessee. 
involved in the suit has tentatively proposed to the court that these states' share of the uncollected consumer settlement fund be used to establish public health projects. The suggested projects include drug abuse programs, community health clinics, and lead poisoning and sickle cell anemia research, which the attorney regards as areas of need for which adequate funding is not politically feasible. ${ }^{37}$

The distribution procedure in the tetracycline actions is not a particularly good example of the cy pres remedy since the uncollected damages have not been used to benfit the plaintiff class of antibiotic purchasers. In fact, the tetracycline procedure may be equivalent to an escheat of the funds to the state under the guise of a typical class action. ${ }^{38}$ When distribution to a next-best class closely approximating the plaintiff class is impractical, there is sufficient flexibility in the cy pres doctrine to permit the state to allocate the funds to other programs designed to maximize public benefit. The goal of the cy pres remedy, however, is to effectuate the normal damage distribution to class members as closely as possible, ${ }^{39}$ and this should be the purpose of the courts whenever feasible.

The concept of utilizing the state as a mechanism for damage distribution to the class as a whole, rather than to individual members, is not entirely new to the courts. Similar procedures have been employed by utilities to refund the collection of excess rates after the imposition of a rate decrease or the denial of a rate increase. Perhaps the most interesting case in this respect is Market Street Railway Go. v. Railroad Commission, ${ }^{40}$ in which the court, after upholding a rate reduction, ordered the railroad to refund excess fares. Fewer than two percent of the excess fares were collected by the injured consumers, however, and the remaining funds were subsequently claimed by both the State of California, through escheat, and the City of San Francisco, as successor to the private railroad company that had charged the excess fares. The court ordered that the funds be given to San Francisco to be used to improve the railroad facilities and thereby to return the funds indirectly to the benefit of the railroad users who had paid the excess fares. ${ }^{41}$

37 Freeman Interview, supra note 35.

38 Two commentators have concluded that the settlement procedure in the tetracycline actions was a parens patriae device. Malina \& Blechman, Parens Patriae Suits for Treble Damages Under the Antitrust Laws, 65 Nw. U.L. REv. 193, 195 (1970).

39 This is true absent any specific indication to the contrary in the legislative history. See note 21 supra.

$4028 \mathrm{Cal} .2 \mathrm{~d} 363$, 171 P.2d 875 (1946).

41 It is unclear whether the court would have given the funds to the successor of the railroad had it been another private company rather than a governmental unit. It should be recognized that where the defendant is allowed to retain illegal profits, some portion 
While this restricted distribution procedure may be useful, some difficulties in it should be noted. The additional benefits actually conferred on a particular class member might be quite remote if the state were allowed to divert to other areas the public funds already budgeted to the area to which the uncollected damages are directed. While the influx of new funds into the public treasury might benefit the plaintiff class along with the general public, recovery of damages would neither specifically accrue to the benefit of the plaintiff class nor approximate recovery by that class as closely as possible. Except for insuring that the desired programs were initiated, a cy pres solution allowing diversion of formerly budgeted funds would serve the same general purpose as an unrestricted escheat to the state. ${ }^{42}$

If the state were enlisted in the distribution of the uncollected damages, ${ }^{43}$ it might be desirable to avoid exposing the courts to pressure from the claims of various possible recipients that their respective causes would best effectuate legislative intent. Instead, a conditional escheat to the states could be made under which the funds would be earmarked for some general purpose, but the details of their disposition would be left to the relevant state agencies, subject to court approval. ${ }^{44}$ The role of the states in such a procedure would be not as ultimate recipient of the funds, but only as intermediary, channeling distribution to the benefit of the plaintiff class.

\section{Distribution Through the Market}

At this time, the cy pres remedy recently suggested in Eisen v. Carlisle of Jacquelin ${ }^{45}$ is perhaps the best known. Eisen brought an action on behalf of himself and several million other investors against the two

of these funds is likely to be used for improvement of facilities. See generally Bebchick v. Public. Util. Comm'n, 318 F.2d 187 (D.C. Cir. 1963) (excess charges ordered held in fund to be used at Commission's discretion to benefit consumers injured by excessive rate increase); Olson v. County of Sacramento, 274 Cal. App. 2d 316, 79 Cal. Rptr. 140 (1969) (Market Street Railway-type recovery approved if damages could not be distributed to individuals who had suffered the loss).

42 The court's function is not to supervise the states in their budgeting, but it would be desirable to allow the states to claim the uncollected damages only on the condition that funds previously allocated to the purpose for which the uncollected damages were earmarked not be redirected to other uses merely because these additional funds were now available.

43 It is conceivable that the court could establish its own program designed to benefit the next-best class, but utilization of the preexisting distribution facilities of the states is more practical.

44 The court should probably still play a major role in defining the next-best class to which the distribution is to be directed. The definition of this class could be set forth in the restrictions placed on the agency in its disposition of the funds.

45 52 F.R.D. 253 (S.D.N.Y. 1971). 
major odd-lot dealers ${ }^{46}$ on the New York Stock Exchange on the ground that they had conspired to monopolize odd-lot trading and to charge excessive fees in violation of the Sherman Act. The district court initially held that the suit was not maintainable as a class action due to insuperable difficulties foreseen in its management as a class action. ${ }^{47}$

On appeal, the Second Circuit determined that the manageability problems did not appear to be insoluble in view of the desirability of providing small claimants with a forum in which to seek redress for alleged large-scale antitrust violations ${ }^{48}$ and that if the class action did prove to be unmanageable, it could be dismissed at a later stage. ${ }^{49}$ In response to the argument that the unnamed class members would not come forward to collect their shares of the recovery, the court stated that it would not allow the class action to proceed if it would benefit no one except the class's attorney and further noted that the amount expended on the paperwork necessary to prove and collect an individual claim might exceed the damages sustained. Nevertheless, it felt that the trial court would be able to fashion procedures to calculate gross damages and to distribute them to a class numbering in the millions. ${ }^{.0}$

On remand, the district court found that while individual damages were impossible to calculate, gross damages could be fairly estimated by analysis of the records of the defendants and the stock exchange without necessitating the filing of a claim by each class member. ${ }^{51}$ The court did not delineate the particulars of the damage distribution procedure that it would use, but it did give preliminary approval to the plaintiff's proposal for a "fluid class recovery." Under this procedure, there would be an initial period after gross damages were determined during which each class member could prove and collect his damages. Subsequently, a fund equivalent to the residue of uncollected damages would be established, and the odd-lot differential in all transactions involving the defendants would be reduced in an amount determined

46 Odd lots are units of stock smaller than one hundred shares. Odd-lot dealers hold inventories of stock from which they sell such small quantities and receive as their fee for this service the "odd-lot differential," which is a fixed per-share amount that varies with the price of the stock.

4741 F.R.D. 147, 151-52 (S.D.N.Y. 1966). The court also found that Eisen inadequately represented the interests of the unnamed class members and that questions affecting individual class members predominated over questions common to the class.

48391 F.2d 555, 566-70 (2d Cir. 1968).

$49 \mathrm{Id}$. at 566 .

$50 \mathrm{Id}$. at 567. The court also held that it was error to base a finding of inadequate representation on the size of the named plaintiff's claim and determined that common questions did predominate over those affecting individual class members.

51 52 F.R.D. 253, 261-62 (S.D.N.Y. 1971). 
by the court until this uncollected damage fund was depleted. ${ }^{52}$ The court indicated that this method would satisfy both its concern that class members actually share in any eventual recovery and its desire to avoid the retention of illegal profits by the defendants. ${ }^{53}$

The Eisen proposal may be the imaginative remedy that is needed to deal with the uncollected damages problem in large class actions in some circumstances, but several difficulties are readily apparent in this price reduction remedy. One is that due to the unwillingness of many class members to prove their damages and the necessity of establishing the quantity available for distribution, price reduction would be feasible only where gross damages could be reasonably estimated from the defendant's records. ${ }^{54}$ Since most businessmen maintain records of sales volume at various prices, however, a reasonable figure can usually be determined. From the perspective of the plaintiff class, any method that could be used to fix individual damages at some figure would be desirable, even if this were a minimum rather than an average damage amount. Class members not satisfied with the per-unit damage figure could request exclusion from the class action and pursue their claims individually. In this respect, courts must maintain a realistic perspective when assessing whether class members will receive all of the safeguards usually accorded in individual suits for damages. For the great majority of consumer class members, the individual suit would not be a viable alternative and dismissal of the class action might effectively deny them all relief.

As a practical matter, moreover, concern with ascertaining gross damages may be unjustified in view of the position taken by courts on the issue. ${ }^{55}$ In Eisen, the court seemed to be satisfied that the records of the defendants and the stock exchange gave sufficient information to

52 Id. at 265. The proposed Eisen remedy has been used previously in the class action context in Daar v. Yellow Cab Co., 67 Cal. 2d 695, 433 P.2d 732, 63 Cal. Rptr. 724 (1967), in which illegal charges were returned to the injured consumers by a reduction of fares that would deplete the settlement fund over a number of years. Letter from Leon Perlsweig, attorney for plaintiff Daar, to The University of Chicago Law Review, Jan. 31, 1972. Eisen is the first class action, however, in which the opinion discusses and gives preliminary approval to such a proposal in the context of a potential judgment awarding damages rather than a settlement. Daar is an uncertain authority outside the settlement context since the court stated that the individuals injured by the overcharge would ultimately have to prove their individual claims. $67 \mathrm{Cal}$. $2 \mathrm{~d}$ at 706, 713, $433 \mathrm{P} .2 \mathrm{~d}$ at 740, 745, $63 \mathrm{Cal}$. Rptr. at 732, 737.

53 52 F.R.D. 253, 264-65 (S.D.N.Y. 1971).

54 It should be noted that this problem is also present when distribution is made through the state.

55 See Bigelow v. RKO Radio Pictures, 327 U.S. 251, 264 (1946); Union Carbide \& Carbon Corp. v. Nisley, 300 F.2d 561, 590 (10th Cir.), petition for cert. dismissed, 371 U.S. 801 (1962). 
arrive at a "reasonable" estimate of gross damages. ${ }^{56}$ Even in Philadelphia v. American Oil Co., ${ }^{57}$ in which there were no records through which each class member could substantiate his claim, the court recognized that statistics of quantity and price would be sufficient for estimating gross damages..$^{58}$

Another problem presented by the price reduction distribution mechanism is that it is based on the assumption that the class of injured persons will still be active in the relevant market, so that their future purchases at lower prices will compensate for their past injury from excessive prices. ${ }^{59}$ It is unclear whether this condition can be satisfied in Eisen, ${ }^{60}$ and application of the price reduction remedy to other fact situations might pose further difficulties. In American Oil, the action was filed on behalf of several classes of gasoline purchasers, including a class of approximately six million retail purchasers in three states, alleging a conspiracy to fix prices by the major gasoline companies and seeking damages that had been accumulated between 1955 and $1965 .{ }^{.1}$ In response to the defendants' argument that the class action was so large as to make the distribution of damages unmanageable, the class's attorney proposed the remedy suggested in Eisen. The court rejected the price reduction remedy, however, on the ground that the retail purchasers during the ten-year period would not be substantially equivalent to the class that would benefit from a prospective price reduction. ${ }^{62}$

An additional difficulty, not considered in Eisen or American Oil, relates to the economic ramifications of price reduction. Both administrative considerations and the fact that class members would be gradually dropping out of the relevant market indicate that any judicially adopted price reduction should be large enough to permit recoupment

56 52 F.R.D. at 261-62.

57 53 F.R.D. 45 (D.N.J. 1971).

58 Id. at 71 .

6952 F.R.D. at 265 . It is this fact that makes the current odd-lot investors the next-best class of recipients of the uncollected funds.

60 No showing was made that the odd-lot investors in 1960, when Eisen began investing, would resemble the class that would benefit from a prospective reduction in the odd-lot differential.

61 58 F.R.D. at $47-49$.

62 Id. at 71-72. But see Wall Street Journal, Mar. 1, 1972, at 21, col. 3 (notice of settlement of hotel telephone charges suit). The District Court for the Northern District of Illinois approved a settlement distirbution procedure whereby the residue of uncollected funds would be depleted by a price reduction of fifty cents in the daily room rate. And in United States v. Chicago Blackhawk Hockey Team, Inc., CCH 1972 ECoN. Contrors REP. If 9998(9), at 9897 (N.D. Ill. Jan. 18, 1972), the court has granted a preliminary injunction in an action seeking that an illegal price increase during Phase One and Phase Two from fifty cents to seventy-five cents for programs sold at home games be refunded through a price reduction or in some other manner as the court might direct. 
of losses over a fairly short time period. The greater the price reduction, however, the more attractive would be the good or service to new purchasers. The increase in the number of new purchasers in the market would create windfalls for nonclass members, and the amount of these windfalls would deplete the fund available for distribution to class members. A similar result would occur where class members who had claimed their shares of the recovery continued to remain active in the market, thereby receiving a double recovery. The market activity of these two classes of purchasers might be sufficient to deny recovery to a very large portion of the silent class members, even assuming that they were still active in the relevant market.

Unless regulated, the Eisen price reduction remedy could also result in enormous windfalls where an enterprising individual bought the entire inventory of goods or services covered by the price reduction and then resold at the normal rate. An adequate safeguard against this type of activity would be to impose a limit on the number of products that any one person could purchase subject to the price reduction. But this would require the compilation of a minute-by-minute cumulative account for each of the thousands or millions of transactions and would involve prohibitive costs, not to mention the possibility of purchases through agents or under different names.

Judicial supervision of price reduction would be further complicated by the possibility that the defendant could reduce the quality of the good or service offered. Any quality reduction would decrease both the value of the good or service and the compensation received by the purchasing class. Where it would be necessary to supervise not only the quality of the product, but also the entire scope of the defendant's business, ${ }^{63}$ the burden placed on the courts would make the price reduction remedy impractical.

Effects on competition must also be taken into account. Depending on the purchasers' responsiveness to the price reduction, the adjusted rate could be attractive enough to divert demand from competing products. This possibility appears remote in a situation such as Eisen, in which the defendants are alleged to have an effective monopoly; but even in that case, there may still be some impact on such industries as mutual funds, which compete for the small investor's dollar. If the Eisen mechanism had been accepted in American Oil, perhaps those most prejudiced by the judgment would have been the independent gasoline distributors, who would have been forced to reduce their prices

63 Any reduction in the services or courtesies usually afforded consumers would partially destroy the distribution effect of the price reduction. 
in order to compete with the artificially low rates of the defendant major oil companies. If one sought to minimize the effect on competition by insuring that the price reduction was sufficiently small so that any such effect would be minimal, the problem of class members dropping out of the relevant market with the passage of time would return. A compromise might be effected by requiring a substantial enough price reduction to distribute the damage fund rapidly, with the stipulation that the existence of the lower price not be advertised to the public in order to minimize the effect on competition.

Under the price reduction remedy, it might also be difficult to terminate the reduction at the precise point at which the uncollected damage fund had been depleted. The economic feasibility of compiling records at the end of each hour, day, or week to insure that the defendant was not being forced to pay more or less than the amount of the damages would depend on the facts of each situation. The volume in some markets is so substantial that the continuation of a price reduction for even an additional day can be significant. In an application of the price reduction remedy to gasoline distributors of a multistate area, the large daily volume of business and the problems and administrative cost of collecting volume and price statistics indicate that the amount eventually distributed to consumers would probably be only a rough approximation of the figure assessed by the court.

\section{Conclusion: Choice of Remedy}

In any case in which relief is to be given to the class as a whole rather than to the individual class members, the plaintiff must confront the traditional doctrine that damages may be claimed only by persons actually injured and that the claims in a class action are nevertheless separate and individual. ${ }^{64}$ The goal of the cy pres remedy is to return the damages to the class members, although it must be recognized that a significant portion of the funds used in this manner will benefit persons other than class members and that some class members will be benefited only indirectly, if at all. Perhaps the best argument for the cy pres remedy in this respect is that as class actions have expanded to the point "where almost everybody is a potential member of the class,"65 the concern for recovery by each class member in the traditional manner decreases in importance.

64 See Snyder v. Harris, 394 U.S. 332 (1969). But see Bangs, Revised Rule 23: Aggregation of Claims for Achievement of Jurisdictional Amount, 10 B.C. IND. \& CoM. L. REv. 601 (1969).

o5 Eisen v. Carlisle \& Jacquelin, 391 F.2d 555, 571 (2d Cir. 1968) (Lumbard, C.J., dissenting). 
Whenever a court determines that a cy pres remedy may be used advantageously, there remains the choice between distribution of all of the damages or only that portion of the damages remaining uncollected after the class members have been afforded an opportunity to file claims. If the cy pres remedy is used for the distribution of all of the damages, then it may be argued that due process will have been denied to those class members who would have brought individual suits, but who are presently bound by a judgment in their favor yet deprived of their shares of the recovery. It is also doubtful whether the named plaintiffs adequately represent the interests of the class if the unnamed class members will not be permitted to collect directly their shares of the damages. ${ }^{66}$ Thus, despite the significant cost of notifying class members of the opportunity to claim damages and of investigating these claims, some period in which claims may be filed is desirable, if not mandatory, in order to insure an opportunity for individual recovery.

It is likely that the aforementioned variations on the cy pres solutions do not exhaust the possible effective distribution techniques which may be used in the large class action context. The combination of the price reduction mechanism and the conditional escheat procedure, however, permits flexibility in formulating a workable distribution procedure.

The acceptability of any cy pres damage distribution mechanism can be best measured by balancing ( 1 ) the extent to which the injured class receives the damages, (2) the cost of applying the remedy, and (3) the equitability of the distribution with respect to the potential of windfalls for nonclass members. Where there is a high degree of identity between the plaintiff class and the persons currently active in the relevant market, the price reduction mechanism may appear most appropriate. Given the multitude of difficulties created by price reduction, on the other hand, it is unlikely that its benefits will often outweigh its inherent disadvantages of administrative and economic feasibility. The conditional escheat remedy, by which the funds given to the state are earmarked, provides a more indirect benefit to the actual injured class and also involves some cost of administering the programs to be established. Yet this remedy appears likely to be more feasible than price reduction in most cases.

If the courts are to carry out the intent of the drafters of rule 23, the cy pres doctrine must be applied to large class actions that result in uncollected damages. Due to the fee incentive, this will probably increase the number of suits that are economically feasible from the perspective 
of the plaintiffs' attorney. But the expansion of rule 23 effected by the 1966 revision will be effectively meaningless unless the persons included in the judgment can also be included in the benefit.

Stewart $R$. Shepherd 